\title{
GENETIC PARAMETERS FOR EGG AND RELATED CHARACTERISTICS OF WHITE LEGHORN HENS IN A SUBTROPICAL ENVIRONMENT ${ }^{1}$
}

\author{
Hani M. Sabri², Henry R. Wilson ${ }^{3}$, Robert H. Harms ${ }^{3}$ and Charles J. Wilcox ${ }^{3}$
}

\begin{abstract}
Estimates of heritability and phenotypic and genetic correlations between egg number, weight, specific gravity, mass, and estimated shell weight were obtained, along with phenotypic and genetic correlations of specific gravity and weight with body weight, weight change, metabolizable energy intake, residual feed consumption, and weight and age at sexual maturity. Data were from 350 White Leghorn hens by 50 sires and 175 dams. Heritabilities of the egg traits ranged from 0.20 to 0.55 , increasing with age of bird from 26 to 54 weeks of age. Their standard errors ranged from 0.07 (all data) to 0.17 (26 to 29 weeks). Phenotypic correlations ranged from 0.80 to -0.13 , and genetic correlations from 0.91 to -0.27 , depending on egg trait. The highest phenotypic and genetic correlations were between egg number and mass. Genetic correlations for specific gravity and estimated shell weight were, with body weight, -0.02 and 0.56 ; weight change, 0.29 and 0.44 ; daily metabolizable energy intake, -0.10 and 0.33 ; residual consumption, -0.16 and 0.11 ; age at sexual maturity, -0.61 and -0.46 , and weight at sexual maturity, 0.02 and 0.63 . Results should contribute to the design of efficient selection programs for economically important traits in hens.
\end{abstract}

\section{INTRODUCTION}

Egg shell quality embodies characteristics such as shell thickness, shell weight, egg specific gravity, shell strength, resistance to breakage, texture, color, etc. In order to study egg shell problems or to select for changes in egg shell characteristics, reliable measurement techniques to define shell characteristics must be available. Measurements such as shell thickness and shell puncture pressure result in destruction of the egg and permit only one measurement per egg. Other tests, such as egg specific gravity, beta-particles and ultrasound, do not destroy the egg and multiple measurements can be obtained. The importance of shell quality, various techniques for evaluating shell quality, and effective utilization of techniques involved have been reviewed by several authors, including Farnsworth and Nordskog (1955), Carter (1968), Nagai and Gowe (1969a,b), Perek and Snapir (1970), Rodda (1972), Potts and Washburn (1974, 1983), Potts et al. (1974), Hamilton et al. (1979), Hamilton (1982), Hunton (1982), Grunder et al. (1989, 1991), Muir and Patterson (1990), Narushin (1997), and others. Most methods used have been capable of distinguishing differences in shell quality due to breed, strain and individual birds. However, most breeding programs put little selection pressure on shell quality, possibly because of the risk of diverting selection pressure away from egg production, egg weight, and other traits (Hunton, 1982), as well as the lack of an effective, non-destructive, evaluation procedure.

${ }^{1}$ Florida Agricultural Experiment Station Journal Series No. R-05397. ${ }^{2}$ Faculty of Agriculture, Animal Production Department, Suez Canal University, Ismailia, Egypt.

${ }^{3}$ Department of Dairy and Poultry Sciences, University of Florida, PO Box 110920, Gainesville, FL 32611-0920, USA. Send correspondence to C.J.W. Fax: 352-392-5595, E-mail: wilcox@dps.ufl.edu
Measurement techniques that can be made early in the production period of the hen are most useful to the breeder, and this seems to be feasible for shell quality evaluations (Nagai and Gowe, 1969a,b). The effectiveness of each technique may vary among breeds and strains tested (Potts et al., 1974); therefore, equations to predict shell quality may differ among strains. Egg specific gravity, with appropriate corrections, has been found to be an acceptable estimator of shell quality (Wells, 1967; Potts and Washburn, 1974; Potts et al., 1974; Hunton, 1982; Abdallah et al., 1993). When taking heritability, genetic correlations and ease of measurement of different shell quality traits into consideration, specific gravity has been the best shell quality trait to use in selection programs (Grunder et al., 1989). However, egg weight is important in determining egg specific gravity, and the two traits are negatively correlated. Abdallah et al. (1993) indicated that percent shell and shell weight per unit of surface area were more sensitive estimates of shell quality (incidence of cracked eggs) than specific gravity. Harms et al. (1990) developed formulas for estimating egg specific gravity or shell weight when only one of the traits was measured. The formulas later were modified to increase accuracy and sensitivity of estimates (Harms et al., 1994).

Objectives of the current study were to estimate genetic parameters for various characteristics of hens and eggs, so that efficient multi-trait selection programs can be developed which will maximize economic return.

\section{MATERIAL AND METHODS}

The data used in this study were collected in conjunction with studies reported earlier by Sabri (1988) and Sabri et al. (1991a,b). Data were obtained from 350 pedigreed hens by 50 sires and 175 dams of a White Leghorn type genetic line (Hy-Line International, Dallas Center, 
IA, USA 50063). Hens were distributed randomly in three rows of individual cages. Water and food were available ad libitum. A standard layer diet (164.5 g protein, 11,820 J) was fed in individual plastic feed cups. Data were obtained during seven 4 -week periods ( 26 to 29,30 to 33,34 to 37,38 to 41,42 to 45,46 to 49 , and 50 to 54 weeks of age). Traits measured for each period were egg number (EN), egg weight (EW), egg specific gravity (SG), body weight $(\mathrm{BW})$, body weight change (BWC), average metabolizable energy intake (ME), and residual feed consumption (RES), measured as metabolizable energy intake adjusted for BW, BWC and egg mass (EM). Age at sexual maturity (SMAGE) and body weight at sexual maturity (SMBW) were recorded for each hen. EN and EW were used to estimate (EN x EW) average EM output per day for each period. Eggs were collected and weighed daily and were used to calculate the average EW for each period. SG was measured twice per week on the day of lay. SG for each hen was represented by the average of SG for each period. SG was measured using procedures of Voisey and Hamilton (1977) with increments of 0.0025. Shell weight (SWe) was determined using EW and SG as described by Harms et al. (1990), as:

$\mathrm{SWe}=(2.0341 \times \mathrm{EW})-[(2.1014 \times \mathrm{EW}) / \mathrm{SG}]$,

in which $\mathrm{SWe}=$ estimated shell weight, $\mathrm{EW}=$ egg weight, and $\mathrm{SG}=$ egg specific gravity. Birds were housed in Gainesville, FL, USA, located at $29^{\circ} 39.6^{\prime} \mathrm{N}$ and $83^{\circ} 49.6^{\prime} \mathrm{W}$, in a climate considered to be subtropical.

Data were analyzed by the method of ordinary least squares analysis of variance using the computer programs of Harvey (1985). Mathematical model included period, sire and dam in sire. Period effects were considered fixed and the remaining effects were considered random. Heritability was estimated as:

$$
\mathrm{h}^{2}=2(\mathrm{~S}+\mathrm{D}) /(\mathrm{S}+\mathrm{D}+\mathrm{E})
$$

where $\mathrm{S}=$ sire; $\mathrm{D}=$ dam, and $\mathrm{E}=$ error components of variance.

\section{RESULTS AND DISCUSSION}

Overall means for EN, EW, EM, SG, and SWe were 20.7 eggs/period, $54.3 \mathrm{~g}, 40.5 \mathrm{~g} /$ day, 1.0813 , and $4.91 \mathrm{~g}$, respectively (Table I). EN, EM, SG and SWe decreased with increased age, whereas EW increased with increased age. All changes with age were statistically significant. Weighted regression analyses of period effects (Table I) indicated a linear decline in SG of 0.00177 per period. All other changes were curvilinear, with a quadratic equation describing EN and cubic equations describing EW, SWe, and EM. The trend was to increase over time for EW but to decrease in the other response variables. The decrease in SG after peak egg production and the increased EW with increased age have been previously reported (for example, see Abdallah et al., 1995). Period effects were included in subsequent analyses of genetic and phenotypic parameters.

Heritabilities estimated using data from all periods for egg traits were moderate (Table II). These values generally agreed with those of several others, e.g., Grunder $e t$ al. (1989), and Muir and Patterson (1990). Heritabilities for period 1 (early) were higher, although not differing statistically, than for period 7 (late) for EN, SG and SWe, with an increase in the standard error of the estimates with increased age. This agreed with Grunder et al. (1989) who estimated heritability of several egg traits at middle intervals of production (42 to 45 weeks of age) and late (67 to 68 weeks of age). They stated that estimates were almost always higher when measured early compared with late in the laying year. Hagger and Abplanalp (1978) and Sabri et al. (1991a) found the same trend when estimating heritability of residual feed consumption, a measure of feed efficiency for egg production. They suggested that the genetic potential of egg production and related traits are well expressed at peak egg production, which minimized effects of environmental factors compared to later times of the laying year. Higher heritabilities at early stages of the laying year are advantageous because early selection decisions can be made.

\section{Phenotypic correlations}

Phenotypic correlations for egg traits were found

Table I

Least squares means for egg traits in White Leghorn hens. ${ }^{1}$

\begin{tabular}{|ccccccc|}
\hline Period $^{2}$ & Age (week) & EN (n) & EW (g) & SG & SWe (g) & EM (g/day) \\
\hline 1 & $26-29$ & 22.4 & 50.6 & 1.0867 & 5.08 & 40.4 \\
2 & $30-33$ & 22.4 & 53.0 & 1.0849 & 5.14 & 42.3 \\
3 & $34-37$ & 22.0 & 54.3 & 1.0838 & 5.17 & 42.6 \\
4 & $38-41$ & 20.9 & 55.4 & 1.0806 & 4.96 & 41.4 \\
5 & $42-45$ & 20.4 & 55.7 & 1.0787 & 4.78 & 40.6 \\
6 & $46-49$ & 19.3 & 55.4 & 1.0776 & 4.65 & 38.1 \\
7 & $50-54$ & 17.9 & 55.6 & 1.0768 & 4.59 & 38.2 \\
\multirow{2}{*}{ Mean } & $26-54$ & 20.7 & 54.3 & 1.0813 & 4.91 & 40.5 \\
& & \pm 0.1 & \pm 0.1 & \pm 0.0001 & \pm 0.01 & \pm 0.1 \\
\hline
\end{tabular}

${ }^{1}$ Traits are EN (egg number per period), EW (egg weight), SG (egg specific gravity), Swe (estimated shell weight), and EM (egg mass).

${ }^{2}$ Period effects were significant and are described as ÊN $=22.5+0.131 \mathrm{x}-$ $0.1114 \mathrm{x}^{2} ; \hat{\mathrm{E} W}=47.1+4.09 \mathrm{x}-0.647 \mathrm{x}^{2}+0.335 \mathrm{x}^{3} ; \mathrm{SG}=1.0866-0.00177 \mathrm{x} ;$ $\mathrm{SWe}=4.738+0.4658 \mathrm{x}-0.14469 \mathrm{x}^{2}+0.010734 \mathrm{x}^{3}$, and $\hat{\mathrm{EM}}=35.78+$ $6.055 \mathrm{x}-1.5954 \mathrm{x}^{2}+0.11093 \mathrm{x}^{3}$, where $1 \leq \mathrm{x} \leq 7$.

Table II

Heritability estimates for egg traits of White Leghorn hens.

\begin{tabular}{|lccc|}
\hline Trait & $\begin{array}{c}\text { Period 1 } \\
(26-30 \text { weeks })\end{array}$ & $\begin{array}{c}\text { Period 7 } \\
(50-54 \text { weeks })\end{array}$ & $\begin{array}{c}\text { All periods } \\
(26-54 \text { weeks })\end{array}$ \\
\hline EN & $0.271 \pm 0.173$ & $0.196 \pm 0.195$ & $0.302 \pm 0.071$ \\
EW & $0.457 \pm 0.174$ & $0.501 \pm 0.194$ & $0.490 \pm 0.071$ \\
EM & $0.307 \pm 0.174$ & $0.427 \pm 0.194$ & $0.400 \pm 0.071$ \\
SG & $0.453 \pm 0.174$ & $0.232 \pm 0.195$ & $0.310 \pm 0.071$ \\
SWe & $0.553 \pm 0.173$ & $0.285 \pm 0.196$ & $0.343 \pm 0.071$ \\
\hline
\end{tabular}

For abbreviations see legend to Table I. 
Table III

Genetic correlations (below the diagonal) with their standard errors and phenotypic correlations (above the diagonal) between different egg traits.

\begin{tabular}{|lccccc|}
\hline Trait & EN & EW & EM & SG & CSW \\
\hline EN & - & -0.132 & 0.831 & 0.019 & -0.060 \\
EW & $0.262 \pm 0.128$ & - & 0.206 & -0.167 & 0.545 \\
EM & $0.910 \pm 0.033$ & $0.120 \pm 0.101$ & - & -0.035 & 0.097 \\
SG & $-0.101 \pm 0.145$ & $-0.162 \pm 0.120$ & $-0.118 \pm 0.129$ & - & 0.798 \\
SWe & $-0.265 \pm 0.146$ & $0.605 \pm 0.074$ & $0.002 \pm 0.122$ & $0.686 \pm 0.060$ & - \\
\hline
\end{tabular}

For abbreviations see legend to Table I.

to be negative between EN and EW, and between EW and SG (Table III). Positive correlations were found between EN and EM, EW and EM, EW and SWe, and SG and SWe. Phenotypic correlations of both SG and SW with economic traits were low. These agreed in sign and generally in value with those of other workers (Muir and Patterson, 1990; Abdallah et al., 1993).

Grunder et al. (1991) reported low phenotypic correlations between egg production traits and shell quality traits or percentage intact eggs and concluded that egg production traits were not good indicators of shell quality or percentage intact eggs, and vice versa. According to Abdallah et al. (1993), SG could be used as a method for predicting the percentage of cracked eggs if SG were determined precisely and if EW were taken into consideration.

\section{Genetic correlations}

Negative genetic correlations were found between SG and EN, EW, and EM (Table III). The negative genetic correlation between EN and SG agreed in sign with those reported by several, for example Grunder et al. (1991). Grunder et al. (1989) reported that EW had a consistently negative but low genetic correlation with percentage intact eggs and a low genetic correlation with SG. Although a heavier egg is expected to have a heavier shell, the high positive genetic correlations between SWe and EW, as well as between SWe and SG, reflect a part/whole correlation because EW and SG were used to calculate shell weight.
Genetic correlations between SG and some economically important traits generally were low in value, except the correlation with SMAGE of -0.611 (Table IV). On the other hand, SWe showed positive genetic correlations with BW, BWC, SMBW and EM of 0.328 to 0.628 , but a negative genetic correlation with SMAGE. Grunder et al. (1991) estimated the genetic correlations between SG and economically important traits (EN, hen-day rate of production, henhoused egg production, SWe, SMAGE, Haugh unit at 240 and 450 days, BW at 365 days, fertility, hatchability and viability). They concluded that genetic correlations with SG were such that they would allow improvement in percentage intact egg without seriously compromising selection objectives for other traits. Using SG as a selection criterion might slightly reduce EW, EM (Table III), and SMAGE (Table IV). However, using SWe as a selection criterion might slightly decrease EN, increase EW (Table III), and positively affect BW traits (Table IV). The expected small effect of the two traits SG and SWe on EN is balanced by their effect on EW. Both SG and SWe traits are not expected to affect EM output or feed efficiency for egg production (RES). Grunder et al. (1989) stated that heritability of percent intact eggs was low, but had a high genetic correlation with SG, as well as other measures of shell quality. These authors suggested that SG would be the best egg shell quality trait for a selection program.

SG and SWe are traits that are easily measured, and multiple measurements are possible if desired. They have the additional advantage that the egg is not destroyed. However, care should be taken to control solution and egg temperature when measuring SG. The use of SG increments of 0.001 or 0.0025 should improve sensitivity within and among laboratories (Harms et al., 1994). Sensitivity and accuracy can also be improved by adjusting for changes in the density of egg contents due to age of the hens (Sloan et al., 1993) and other factors. The results of this study also suggest the potential for using early measurements of SWe in selection programs, which has definite advantages

\section{Table IV}

Genetic correlations $\left(r_{A}\right)$ with their standard errors and phenotypic correlations $\left(r_{p}\right)$ between both SG and SWe and various economically important egg traits ${ }^{1}$.

\begin{tabular}{|c|c|c|c|c|c|c|}
\hline Trait & BW & BWC & $\mathrm{ME}$ & RES & SMAGE & SMBW \\
\hline \multicolumn{7}{|l|}{ SG } \\
\hline $\mathrm{r}_{\mathrm{A}}$ & $-0.019 \pm 0.089$ & $0.294 \pm 0.219$ & $-0.099 \pm 0.093$ & $-0.157 \pm 0.149$ & $-0.611 \pm 0.153$ & $0.022 \pm 0.115$ \\
\hline $\begin{array}{l}\mathrm{r}_{\mathrm{p}} \\
\mathrm{SWe}\end{array}$ & 0.022 & 0.119 & 0.051 & 0.006 & -0.031 & 0.018 \\
\hline $\mathrm{r}_{\mathrm{A}}$ & $0.559 \pm 0.221$ & $0.444 \pm 0.079$ & $0.328 \pm 0.084$ & $0.119 \pm 0.142$ & $-0.456 \pm 0.139$ & $0.628 \pm 0.105$ \\
\hline$r_{p}^{A}$ & 0.148 & 0.225 & 0.221 & -0.002 & 0.040 & 0.185 \\
\hline
\end{tabular}

${ }^{1}$ Traits are BW (body weight), BWC (body weight change), ME (metabolizable energy intake per day), RES (residual feed consumption), SMAGE (sexual maturity age), SMBW (sexual maturity body weight), SG (egg specific gravity), and SWe (estimated shell weight). 
to breeders (Hagger and Abplanalp, 1978; Sabri et al., 1991a). Grunder et al. (1989) suggested that SG would be the best egg shell quality trait for a selection program based on heritability, genetic correlation with percent intact eggs, and ease of measurement. However, negative genetic correlations of SG with EW and EM would suggest that SWe has greater potential for use in breeding programs for improving egg shell quality and as an indicator of the hen's ability to metabolize and secrete calcium and other egg shell components.

\section{ACKNOWLEDGMENTS}

The authors wish to acknowledge Hy-Line International, Dallas Center, IA 50063 who supplied the birds used in this study. The authors gratefully acknowledge Rafael M. Roman for statistical analyses of time trends.

\section{RESUMO}

Estimativas de herdabilidade e correlações fenotípicas e genéticas entre o número de ovos, peso, gravidade específica, massa e peso estimado da casca foram obtidas, assim como correlações fenotípicas e genéticas de gravidade específica e peso com peso corporal, alterações ponderais, ingestão de energia metabolizável, consumo alimentar residual e peso e idade ao atingir a maturidade sexual. Os dados foram obtidos de 350 galinhas da raça Leghorn Branca obtidas de 50 pais e 175 mães. A herdabilidade dos caracteres dos ovos variou de 0,20 a 0,55 , aumentando com a idade da ave de 26 a 54 semanas. O desvio padrão variou de 0,07 (todos os dados) a 0,17 ( 26 a 29 semanas). As correlações fenotípicas variaram de 0,80 a $-0,13$ e as correlações genéticas de 0,91 a $-0,27$, dependendo do caracter do ovo. As correlações fenotípicas e genéticas mais elevadas foram entre o número de ovos e a massa. As correlações genéticas para gravidade específica e peso estimado da casca foram, com o peso corporal, - $-0,02$ e 0,56; com alterações do peso, 0,29 e 0,44; com a ingestão diária de energia metabolizável, $-0,10$ e 0,33 ; com o consumo residual, $-0,16$ e 0,11 ; com a idade quando do amadurecimento sexual, $-0,61$ e $-0,46$, e com o peso quando do amadurecimento sexual, 0,02 e 0,63 . Os resultados devem contribuir para o delineamento de programas eficazes de seleção para caracteres economicamente importantes em galinhas.

\section{REFERENCES}

Abdallah, A.G., Harms, R.H. and El-Husseiny, O. (1993). Various methods of measuring shell quality in relation to percentage of cracked eggs. Poul. Sci. 72: 2038-2043.

Abdallah, A.G., Harms, R.H. and Russell, G.B. (1995). Effect of age and resting on hens laying eggs with heavy or light shell weight. J. Appl. Poult. Res. 4: 131-137.

Carter, T.C. (1968). The hen's egg: estimation of egg mean and flock mean shell thickness. Br. Poult. Sci. 9: 343-357.

Farnsworth Jr., G.M. and Nordskog, A.W. (1955). Breeding for egg quality. 3. Genetic differences in shell characteristics and other egg quality factors. Poult. Sci. 34: 16-26.

Grunder, A.A., Hamilton, R.M.G., Fairfull, R.W. and Thompson, B.K. (1989). Genetic parameters of egg shell quality traits and percentage of eggs remaining intact between oviposition and grading. Poult. Sci. 68: $46-54$.
Grunder, A.A., Fairfull, R.W., Hamilton, R.M.G. and Thompson, B.K. (1991). Correlations between measures of eggshell quality or percentage of intact eggs and various economic traits. Poult. Sci. 70: 1855-1860.

Hagger, C. and Abplanalp, H. (1978). Food consumption records for the genetic improvement of income over food costs in laying flocks of White Leghorns. Br. Poult. Sci. 19: 651-667.

Hamilton, R.M.G. (1982). Methods and factors that affect the measurement of egg shell quality. Poult. Sci. 61: 2022-2039.

Hamilton, R.M.G., Hollands, K.G., Voisey, P.W. and Grunder, A.A. (1979). Relationship between egg shell quality and shell breakage and factors that affect shell breakage in the field - a review. World's Poult. Sci. J. 35: 177-190.

Harms, R.H., Rossi, A.F., Sloan, D.R., Miles, R.D. and Christmas, R.B. (1990). A method for estimating shell weight and correcting specific gravity for egg weight in eggshell quality studies. Poult. Sci. 69: 4852

Harms, R.H., Abdallah, A.G. and Sloan, D.R. (1994). Errors in measuring and calculating eggshell quality. Poult. Sci. 73: 599-602.

Harvey, W.R. (1985). User's Guide for Mixed Model Least-Squares and Maximum Likelihood Computer Program. Mimeo Rpt., The Ohio State University, Columbus, $\mathrm{OH}$.

Hunton, P. (1982). Genetic factors affecting egg shell quality. World's Poult. Sci. J. 38: 75-84.

Muir, W.M. and Patterson, D.L. (1990). Genetic and environmental associations of uncollectible egg production with shell quality, rate of lay, and erratic timing of oviposition in White Leghorn hens. Poult. Sci. 69: 509-516.

Nagai, J. and Gowe, R.S. (1969a). Genetic control of egg quality. 1. Sources of variation. Br. Poult. Sci. 10: 337-350.

Nagai, J. and Gowe, R.S. (1969b). Genetic control of egg quality. 2. Selection for maximum rate of improvement. Br. Poult. Sci. 10: 351-358.

Narushin, V.G. (1997). Non-destructive measurements of egg parameters and quality characteristics. World's Poult. Sci. J. 53: 141-153.

Perek, M. and Snapir, N. (1970). Interrelationships between shell quality and egg production and egg and shell weights in White Leghorn and White Rock hens. Br. Poult. Sci. 11: 133-145.

Potts, P.L. and Washburn, K.W. (1974). Shell evaluation of white and brown egg strains by deformation, breaking strength, shell thickness and specific gravity. 1. Relationship to egg characteristics. Poult. Sci. 53: 1123-1128.

Potts Sr., P.L. and Washburn, K.W. (1983). The relationship of age, method of measuring, and strain on variation in shell strength. Poult. Sci. 62: 239-246.

Potts, P.L., Washburn, K.W. and Hale, K.K. (1974). Shell evaluation of white and brown egg strains by deformation, breaking strength, shell thickness and specific gravity. 2. Stepwise regression analysis of egg characteristics on methods of assessing shell strength. Poult. Sci. 53: 2167-2174.

Rodda, D.D. (1972). Breeding for late egg shell quality in the domestic hen. Br. Poult. Sci. 13: 45-60.

Sabri, H.M. (1988). Inheritance of feed efficiency in laying hens measured as metabolizable energy intake adjusted for body weight and egg production. Ph.D. thesis, University of Florida, Gainesville, FL.

Sabri, H.M., Wilcox, C.J., Wilson, H.R. and Harms, R.H. (1991a). Measurements of genetic variation in residual metabolizable energy intake of laying hens. Poult. Sci. 70: 222-228.

Sabri, H.M., Wilson, H.R., Wilcox, C.J. and Harms, R.H. (1991b). Comparison of energy utilization efficiency among six lines of White Leghorns. Poult. Sci. 70: 229-233.

Sloan, D.R., Harms, R.H., Abdallah, A.G., Kuchinski, K.K. and Hussein, S.M. (1993). Influence of age of hen on density of egg content. Poult. Sci. 72 (Suppl. 1): 193 (Abstract).

Voisey, P.W. and Hamilton, R.M.G. (1977). Sources of error in egg specific gravity measurements by the flotation method. Poult. Sci. 56: 1457-1462.

Wells, R.G. (1967). Egg shell strength. 2. The relationship between egg specific gravity and egg shell formation and their reliability as indicators of shell strength. Br. Poult. Sci. 8: 193-199.

(Received February 26, 1998) 